\title{
Methionine templated analcime for enhancing heavy metal adsorption
}

\author{
Salma Ehsani Tilami ${ }^{\mathrm{a}, *}$, Seyed Naser Azizi ${ }^{\mathrm{b}}$ \\ a Department of Educational Science, Farhangian University, Tehran, Iran \\ b Analytical Division, Faculty of Chemistry, University of Mazandaran, Babolsar, Iran \\ *Corresponding author, e-mail: salmaehsani@yahoo.com
}

Received 1 Mar 2016

Accepted 4 Mar 2017

\begin{abstract}
Zeolites are effective adsorbents to remove heavy metals from aqueous solutions. To investigate the role of the template on enhancing the ability of zeolites to absorb metals, methionine amino acid was introduced to zeolite synthesis gel to produce a modified analcime zeolite. Afterwards, adsorption of $\mathrm{Cu}$ (II) and $\mathrm{Ni}$ (II) cations on templatefree analcime and methionine-templated analcime were studied and the experimental data were fitted with Freundlich and Langmuir equations in order to obtain the sorption parameters. Batch experiments were carried out to evaluate $\mathrm{Cu}$ (II) and $\mathrm{Ni}$ (II) adsorption at different $\mathrm{pH}$ values, heavy metals concentrations, and removal intervals. The results showed that the metal removal efficiency was strongly dependent on the $\mathrm{pH}$ of the solutions. The analcime zeolites absorbed $\mathrm{Cu}$ (II) more readily than Ni(II). Furthermore, methionine-templated analcime exhibited a higher potential for heavy metal removal than the template-free zeolite. Raman spectra indicated that the presence of a methionine template during analcime zeolite synthesis could create a complex structure of $\mathrm{Cu}-\mathrm{S}$ (methionine)/zeolite and $\mathrm{Ni}-\mathrm{S}$ (methionine)/zeolite. Thus introducing a sulphur-containing template such as methionine may give further possibilities to improve the metal removal efficiency of zeolites.
\end{abstract}

KEYWORDS: organic additive, zeolite

\section{INTRODUCTION}

Heavy metals are the most important pollutants in the environment and widely found on water surfaces from natural and industrial sources ${ }^{1}$. Among metals, the two important pollutant are $\mathrm{Cu}$ and $\mathrm{Ni}$ cations. $\mathrm{Cu}$ ions can deposit in brain, skin, liver, pancreas, and myocardium causing serious toxicological effects on humans ${ }^{2,3}$. $\mathrm{Ni}$ is a commonly toxic metal in natural ecosystems. The most common adverse health effect of nickel in humans is an allergic reaction in direct contact with the skin caused by jewellery or other items containing nickel.

There are several methods for removing heavy metals from waste water such as adsorption, chemical precipitation, ion exchange, electrochemical treatment, solvent extraction, and membrane separation $^{4,5}$. Nowadays, a number of low cost adsorbent materials such as zeolites are available to remove metal ions ${ }^{6-8}$.

Zeolites are hydrated aluminosilicate minerals and have a micro-porous structure. Moreover, the zeolites can be modified by the introduction of new functional groups in order to improve its activity and selectivity for the removal of several substances ${ }^{9}$. There are several applications of pretreated natural zeolites for removing metals from wastewater. For example, natural and sodium pretreated zeolites can take up (remove by ion exchange) lead, nickel, cadmium, and barium ions ${ }^{10}$. Furthermore, the Na pretreated zeolite can be used to take up lead and cadmium from wastewater with an increased ion exchange capacity ${ }^{11}$. The removal efficiency of the metal Bulgarian zeolite pretreated with $\mathrm{NaCl}$, $\mathrm{CH}_{3} \mathrm{COONa}$, and $\mathrm{NaOH}$ solutions is able to remove copper ions ${ }^{12}$.

Methionine, an essential amino acid, is one of the two sulphur-containing amino acids. The data on the complexation of essential metal ions and the bioactive ligands methionine and cysteine give approach into many physicochemical processes ${ }^{13}$. Animal studies have shown that adding methionine to the drinking water of rats protect the animals from the toxic effects of lead ${ }^{14}$. In a separate experiment, it also protects the animals from the toxic effects of mercury and atrazine (a herbicide) ${ }^{15}$.

In our previous work, the effect of D-methionine on the transformation of the structure of zeolite $\mathrm{Y}$ to analcime and zeolite P was investigated and these two zeolites were synthesized in the presence of D-methionine as a template ${ }^{16}$. In this study, the removal of $\mathrm{Cu}(\mathrm{II})$ and $\mathrm{Ni}(\mathrm{II})$ cations was studied to 
evaluate the effect of methionine amino acid on the adsorption ability of methionine template analcime with respect to template-free analcime.

\section{MATERIALS AND METHODS}

Methionine template analcime and template-free analcime were obtained according to the reported procedure ${ }^{16}$. The reagents $\mathrm{D}$-methionine, silicic acid, $\mathrm{NaOH}$, and aluminium powder (all purchased from Merck) were used in the synthesis. All aqueous solutions were prepared using deionized doubly distilled water. The sol-gel mixture was prepared by mixing an aluminate and a silicate solution. Aluminium powder $(0.108 \mathrm{~g})$ was dissolved in a $3.3 \mathrm{M}$ caustic solution at $40^{\circ} \mathrm{C}$ to yield the aluminate solution. $\mathrm{NaOH}(25 \mathrm{ml}, 2.5 \mathrm{M})$ was mixed with silicic acid $(5.9 \mathrm{~g})$ in a Teflon bottle and stirred until the solid is completely dissolved to yield the silicate solution. Afterwards, the aluminate solution was added to the silicate solution with stirring to produce the sol gel. The amino acid D-methionine was dissolved in $\mathrm{H}_{2} \mathrm{O}(4 \mathrm{ml})$ followed by heating to $50^{\circ} \mathrm{C}$. Subsequently, the warmed D-methionine solution was added to the aluminosilicate sol-gel. After the addition was completed, the Teflon bottle was transferred to a stainless-steel autoclave and the sealed autoclave was put into an air oven and heated for $96 \mathrm{~h}$ at $160^{\circ} \mathrm{C}$. The solid products were recovered by filtration or centrifugation and washed with deionized water, dried overnight at $100^{\circ} \mathrm{C}$, and calcinated at $550^{\circ} \mathrm{C}$ for $4 \mathrm{~h}$ in an electric furnace.

Stock solutions were prepared by dilution of analytical grade $\mathrm{CuSO}_{4} \cdot 5 \mathrm{H}_{2} \mathrm{O}$ and $\mathrm{NiSO}_{4} \cdot 6 \mathrm{H}_{2} \mathrm{O}$ salts with distilled water.

\section{Batch adsorption studies}

The adsorption tests were performed by the batch technique at $30^{\circ} \mathrm{C}$. For isothermal studies, the amounts of pre-weighed zeolite $(0.01 \mathrm{~g})$ as adsorbents were placed in adsorption cells containing $10 \mathrm{ml}$ of $\mathrm{Cu}(\mathrm{II})$ and $\mathrm{Ni}(\mathrm{II})$ solutions with a certain initial concentration. The solution $\mathrm{pH}$ was kept at 6 adjusted by $0.1 \mathrm{M} \mathrm{HCl}$ and $\mathrm{NaOH}$ solution. The cells were then agitated in an orbital shaker at $100 \mathrm{rpm}$ and liquid samples were taken out at a given interval for $\mathrm{Cu}$ (II) or $\mathrm{Ni}$ (II) adsorption analyses.

The effect of $\mathrm{pH}$ on the adsorption of heavy metal ions was also investigated at different $\mathrm{pH}$ values. While the solution $\mathrm{pH}$ varied from $2-8$, the amount of adsorbents, the initial concentration of heavy metal ions, and the solution temperature were fixed at $0.01 \mathrm{~g}, 20 \mathrm{mg} / 1$ and $30^{\circ} \mathrm{C}$, respectively.

\section{Analytical Procedures}

Energy dispersive X-ray (EDX) spectra were recorded on an EDX Genesis XM2 attached to FE-SEM. Raman spectra on the samples were obtained using the Nicolet Almega Dispersive Raman (Thermo Scientific, USA) spectrometer consisting of a laser operating at the maximum power of $100 \mathrm{~mW}$ at $532 \mathrm{~nm}$.

\section{RESULTS AND DISCUSSION}

Although the modification of a zeolite increase its price, this work used methionine which is abundant and inexpensive. Because of methionine low price it can be used as a fairly common ingredient to pet food too.

\section{Dynamic adsorption of $\mathrm{Cu}(\mathrm{II})$ and $\mathrm{Ni}(\mathrm{II})$}

The adsorption of $\mathrm{Cu}$ (II) and $\mathrm{Ni}$ (II) on the analcime zeolites was first investigated at different time intervals. As shown in Fig. 1, Cu(II) and Ni(II) adsorption approached maximum after $14 \mathrm{~h}$ and $10 \mathrm{~h}$, respectively. At the same initial concentration, the amounts of adsorbed $\mathrm{Cu}$ (II) and $\mathrm{Ni}(\mathrm{II})$ on analcime zeolites were significantly different and followed the order of $\mathrm{Cu}$ (II) $>\mathrm{Ni}$ (II). In addition, methionine template analcime showed higher adsorption than template-free analcime.

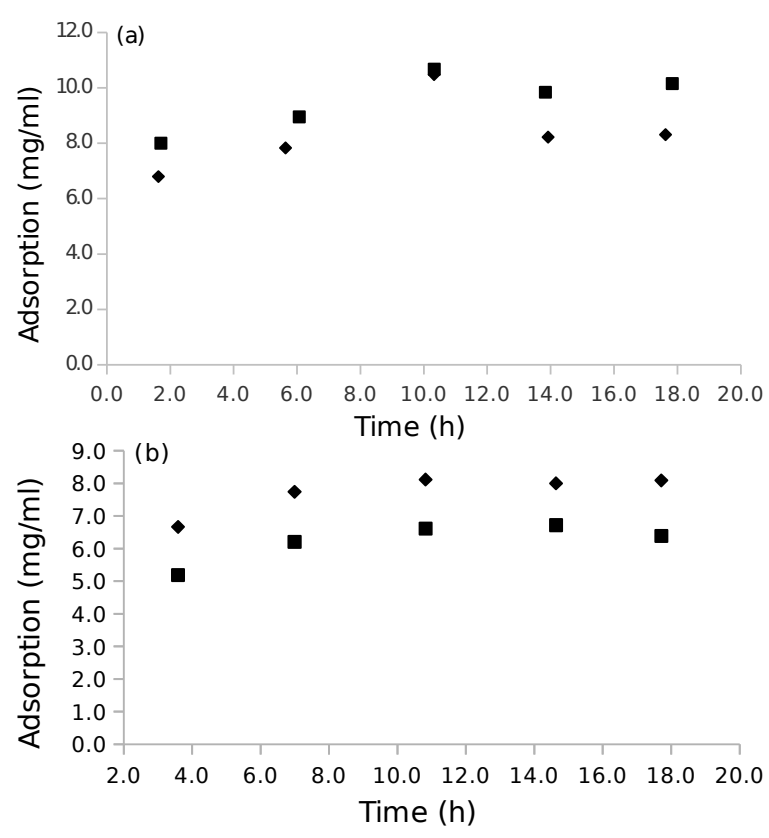

Fig. 1 Dynamic adsorption of (a) Ni(II) and (b) $\mathrm{Cu}$ (II) on methionine template analcime (squares) or free template analcime (diamonds). 


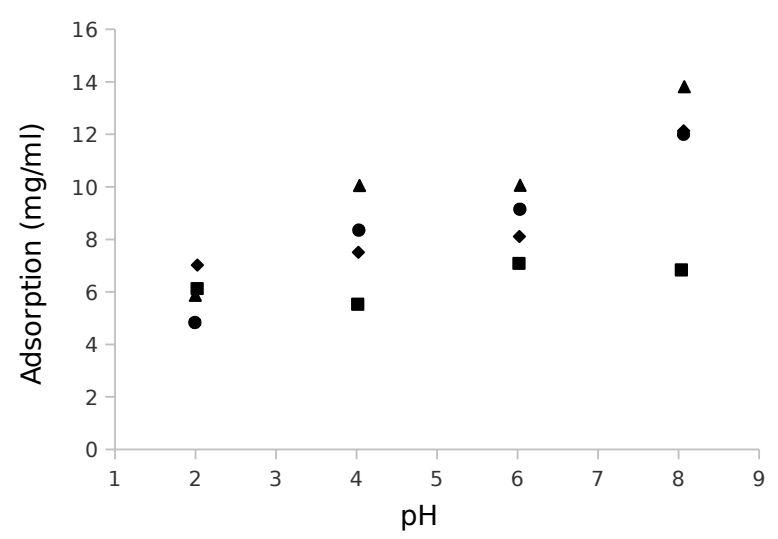

Fig. 2 Effect of $\mathrm{pH}$ on $\mathrm{Cu}(\mathrm{II})$ and $\mathrm{Ni}(\mathrm{II})$ adsorption on methionine template analcime (diamonds) and free template analcime zeolites (squares) and $\mathrm{Cu}$ (II) adsorption on methionine template analcime (triangles) and free template analcime zeolites (circles). Adsorption conditions: $T=30^{\circ} \mathrm{C},[\mathrm{Cu}(\mathrm{II})]=20 \mathrm{ppm}$, and $[\mathrm{Ni}(\mathrm{II})]=20 \mathrm{ppm}$.

\section{Effect of $\mathbf{p H}$}

Fig. 2 shows the effect of $\mathrm{pH}$ on $\mathrm{Cu}(\mathrm{II})$ and $\mathrm{Ni}(\mathrm{II})$ adsorption on methionine template analcime and template-free analcime zeolite. The removal of metals was highly dependent on $\mathrm{pH}$. It was found that with increasing $\mathrm{pH}$, adsorption of $\mathrm{Ni}(\mathrm{II})$ and $\mathrm{Cu}(\mathrm{II})$ exhibited the same trend; higher $\mathrm{Ni}(\mathrm{II})$ and $\mathrm{Cu}(\mathrm{II})$ adsorption were achieved in solutions of higher $\mathrm{pH}$. Chemical precipitation was avoided by keeping the maximum $\mathrm{pH}$ below that of the metal hydroxide precipitation. It is well known that zeolites can adsorb heavy metals via ion-exchange mechanism. The $\mathrm{pH}$ level of the aqueous solution influenced the adsorption of metals to the zeolite via a competition with hydrogen ions. As the $\mathrm{pH}$ level increase, the concentration of the competing hydrogen ions decrease and this causes an increase in the amounts of adsorbed metals ${ }^{17}$.

\section{Adsorption isotherms}

Two adsorption isotherms, Langmuir and Freundlich isotherms, were employed to calculate the adsorption capacity. Freundlich proposed the equation

$$
\log q=\log K_{\mathrm{F}}+\frac{1}{n} \log C_{\mathrm{e}},
$$

where $q$ is the amount of adsorbed cations per gram of zeolite, $C_{\mathrm{e}}$ is the equilibrium concentration of cations, and $K_{\mathrm{F}}$, the Freundlich constant, indicates the adsorption capacity of the zeolite ${ }^{18}$. The Langmuir model assumes that the adsorption occurred on surface sites where the energy in each site is
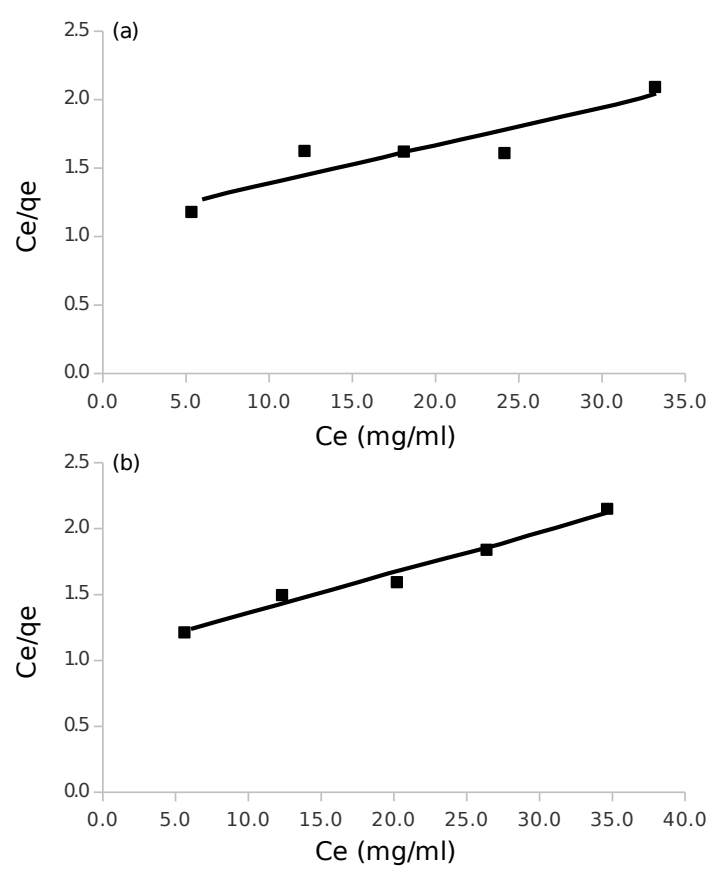

Fig. 3 Langmuir isotherm for Ni(II) adsorption on (a) methionine template analcime: $y=0.025 x+1.024\left(R^{2}=\right.$ 0.834); and (b) free template analcime: $y=0.031 x+$ $1.056\left(R^{2}=0.974\right)$.

equal. The linear form of Langmuir equation is

$$
\frac{C_{\mathrm{e}}}{q_{\mathrm{e}}}=\frac{C_{\mathrm{e}}}{q_{\mathrm{m}}}+\frac{1}{K_{\mathrm{L}} q_{\mathrm{m}}}
$$

where $q_{\mathrm{e}}$ is equilibrium concentration on adsorbent ( $\mathrm{mg} / \mathrm{g}), q_{\mathrm{m}}$ is the saturation capability $(\mathrm{mg} / \mathrm{g}$ ), and $K_{\mathrm{L}}$ is the Langmuir adsorption constant $(\mathrm{l} / \mathrm{mg})$. The constant $K_{\mathrm{L}}$ and the saturation capability $q_{\mathrm{m}}$ can be evaluated by the regression analysis of the linear form of the foregoing equation. Capacity and $1 / n$ is an exponent associated with the adsorptive strength as well as the favourability ${ }^{2}$.

The experimental equilibrium data for $\mathrm{Ni}(\mathrm{II})$ and $\mathrm{Cu}$ (II) adsorption on methionine template analcime and template-free analcime were fitted by the Langmuir and Freundlich isotherms (Figs. 3 and 4). The adsorption data is listed in Table 1.

The results showed that both mathematical models, either Langmuir or Freundlich, fitted the data well. However, the regression coefficients obtained from the Freundlich isotherm were higher than that of the Langmuir isotherm, which suggested the heterogeneous adsorption of $\mathrm{Ni}(\mathrm{II})$ and $\mathrm{Cu}$ (II) on methionine template analcime and template-free analcime zeolite. From the Langmuir model, the calculated parameters at the maximum 
Table 1 Calculated Langmuir and Freundlich constants of the adsorption isotherms of Ni(II) or Cu(II) on zeolites.

\begin{tabular}{|c|c|c|c|c|c|c|c|}
\hline \multirow[t]{2}{*}{ Cation } & \multirow[t]{2}{*}{ Adsorbent } & \multicolumn{3}{|c|}{ Langmuir isotherm } & \multicolumn{3}{|c|}{ Freundlich isotherm } \\
\hline & & $q_{\mathrm{m}}(\mathrm{mg} / \mathrm{g})$ & $K_{\mathrm{L}}(1 / \mathrm{mg})$ & $R^{2}$ & $K_{\mathrm{F}}$ & $1 / n$ & $R^{2}$ \\
\hline \multirow[t]{2}{*}{$\mathrm{Ni}(\mathrm{II})$} & Methionine templated analcime & 40 & 0.024 & 0.834 & 1.39 & 0.732 & 0.978 \\
\hline & Free template analcime & 32.225 & 0.029 & 0.974 & 1.38 & 0.689 & 0.987 \\
\hline \multirow[t]{2}{*}{$\mathrm{Cu}(\mathrm{II})$} & Methionine templated analcime & 62.5 & 0.019 & 0.903 & 1.53 & 0.812 & 0.984 \\
\hline & Free template analcime & 45.45 & 0.022 & 0.901 & 1.37 & 0.756 & 0.99 \\
\hline
\end{tabular}
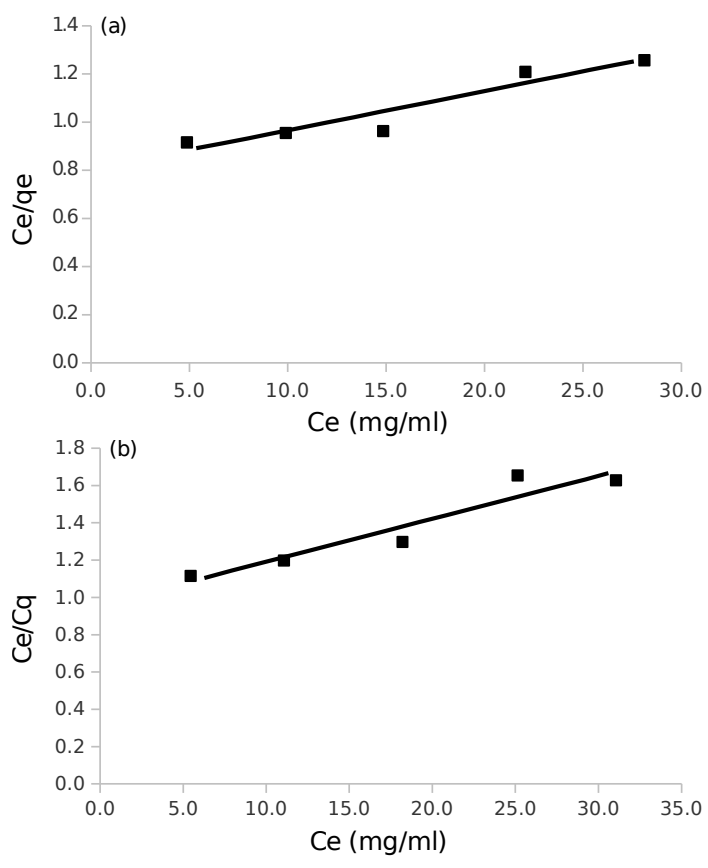

Fig. 4 Langmuir isotherm for $\mathrm{Cu}(\mathrm{II})$ adsorption on (a) methionine template analcime: $y=0.016 x+0.802\left(R^{2}=\right.$ 0.903); and (b) free template analcime: $y=0.022 x+$ $0.970\left(R^{2}=0.901\right)$.

uptake of $\mathrm{Cu}(\mathrm{II})$ and $\mathrm{Ni}(\mathrm{II})$ for methionine template analcime were 62.5 and $40(\mathrm{mg} / \mathrm{g})$ and for template-free analcime were 45.4 and 32.25 , respectively. Based on the Freundlich isotherm, the maximum adsorption capacity of $\mathrm{Cu}(\mathrm{II})$ and $\mathrm{Ni}(\mathrm{II})$ were 1.44 and 1.42 for methionine template analcime while they were 1.38 for the both template and template-free analcime.

The results indicated that a greater uptake of $\mathrm{Cu}$ (II) took place compared to $\mathrm{Ni}(\mathrm{II})$ under the same conditions of $\mathrm{pH}$, initial metal concentration, and adsorbent concentration. This affinity is in agreement with the reports for other hydrous solids such as activated carbon ${ }^{19}$ and has been related to the first equilibrium hydrolysis constant $\left(-\log K_{1}\right)$ : $\mathrm{Cu}(\mathrm{II})=7.9$ and $\mathrm{Ni}(\mathrm{II})=9.9$. It has been confirmed

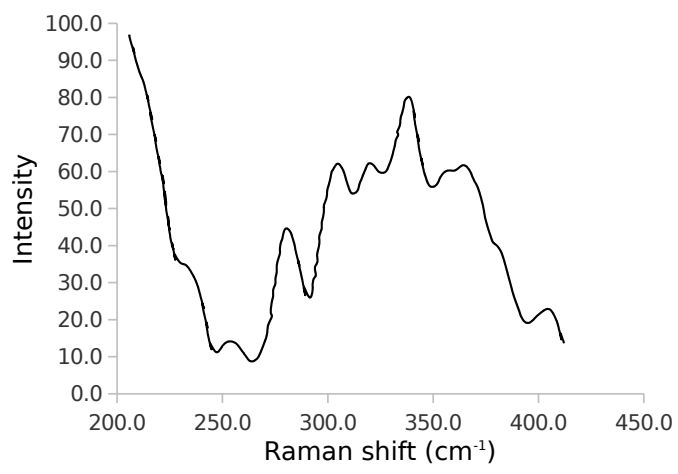

Fig. 5 Resonance Raman spectrum of copper-methionine template analcime.

that higher first hydrolysis constantly lowers the degree of solvation of metal ions ${ }^{20}$. Furthermore, the results indicated that methionine template analcime shows higher adsorption ability than template-free analcime.

\section{Analysis of methionine template analcime adsorption by energy dispersive X-ray and Raman techniques}

To investigate methionine effect on adsorption of $\mathrm{Cu}(\mathrm{II})$ and $\mathrm{Ni}(\mathrm{II})$ ions, the elemental analyses of the methionine template analcime were carried out by energy dispersive X-ray (EDX). In conclusion, a sulphur peak in the EDX spectrum of methionine template analcime confirmed the existence of sulphur atoms in this zeolite.

In addition, the Raman resonance technique was applied to characterize $\mathrm{Cu}-\mathrm{S}$ and $\mathrm{Ni}-\mathrm{S}$ bond stretching frequencies. The Raman spectrum of methionine template zeolite after adsorption of $\mathrm{Cu}(\mathrm{II})$ and $\mathrm{Ni}$ (II) reveals the existence of $\mathrm{Cu}-\mathrm{S}$ and $\mathrm{Ni}-\mathrm{S}$ linkage (Figs. 5 and 6).

The data provides strong evidence for the assignment of low-frequency $\left(\sim 350-400 \mathrm{~cm}^{-1}\right)$ peak in the resonance Raman spectra of the blue coppermethionine as a $\mathrm{Cu}-\mathrm{S}$ (methionine) stretching vibration ${ }^{20}$ and low-frequency $\left(\sim 412 \mathrm{~cm}^{-1}\right)$ peak as a Ni-S (methionine) stretching vibration ${ }^{21}$. 


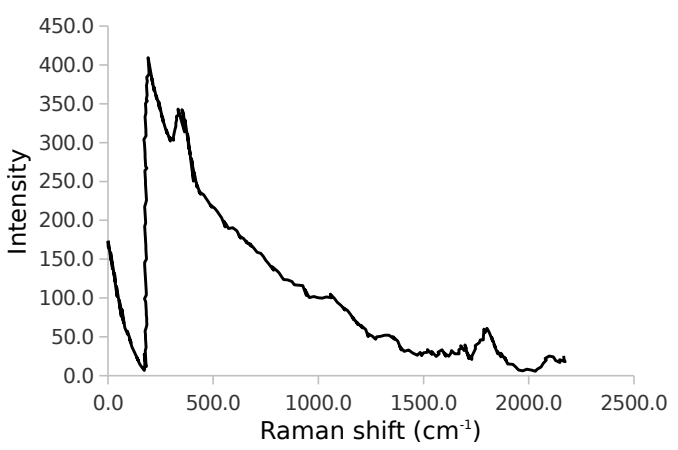

Fig. 6 Resonance Raman spectrum of nickel-methionine template analcime.

\section{CONCLUSIONS}

The results indicated that both methionine template analcime and template-free analcime zeolites effectively adsorb $\mathrm{Ni}(\mathrm{II})$ and $\mathrm{Cu}(\mathrm{II})$ ions in aqueous solution with an adsorption capacity in the sequence $\mathrm{Cu}(\mathrm{II})>\mathrm{Ni}(\mathrm{II})$. In addition, these heavy metals exhibited an increased affinity to the methionine template analcime zeolite surface with respect to template-free analcime. The $\mathrm{Cu}-\mathrm{S}$ and $\mathrm{Ni}-\mathrm{S}$ bonds between methionine and heavy metals may be a good confirmation for the higher adsorption capacity of methionine template analcime.

It is believed that this new adsorption method, which is based on modifying the zeolite synthesis gel by adding the template containing sulphur in the gel system, could have a good potential for future applications of adsorption of pollutants on other zeolites.

\section{REFERENCES}

1. Wang S, Wu H (2006) Environmental-benign utilisation of fly ash as low-cost adsorbents. J Hazard Mater 136, 482-501.

2. Wang S, Terdkiatburana T, Tadé MO (2008) Single and co-adsorption of heavy metals and humic acid on fly ash. Separ Purif Tech 58, 353-8.

3. Veli S, Alyüz B (2007) Adsorption of copper and zinc from aqueous solutions by using natural clay. J Hazard Mater 149, 226-33.

4. Huang CP, Blankenship DW (1984) The removal of mercury(II) from dilute aqueous solution by activated carbon. Water Res 18, 37-46.

5. Panday KK, Parsad G, Singh VN (1985) Copper(II) removal from aqueous solutions by fly ash. Water Res 19, 869-73.

6. Crini G (2006) Non-conventional low-cost adsorbents for dye removal: A review. Bioresour Tech 97, 1061-85.
7. Cochrane EL, Lu S, Gibb SW, Villaescusa I (2006) A comparison of low-cost biosorbents and commercial sorbents for the removal of copper from aqueous media. J Hazard Mater 137, 198-206.

8. Li XG, Feng H, Huang MR (2008) Natural sorbents for mercury-ion removal. Progr Chem 20, 233-8.

9. Dentel SK, Jamrah AI, Sparks DL (1998) Sorption and cosorption of 1,2,4-trichlorobenzene and tannic acid by organo-clays. Water Res 32, 3689-97.

10. Faghihian H, Marageh GM, Kazemian H (1999) The use of clinoptilolite and its sodium form for removal of radioactive cesium, and strontium from nuclear wastewater and $\mathrm{Pb}^{2+}, \mathrm{Ni}^{2+}, \mathrm{Cd}^{2+}, \mathrm{Ba}^{2+}$ from municipal wastewater. Appl Radiat Isot 50, 655-60.

11. Curkovic L, Cerjan-Stefanovic S, Filipan T (1997) Metal ion exchange by natural and modified zeolites. Water Res 31, 1379-82.

12. Panayotova MI (2001) Kinetics and thermodynamics of copper ions removal from wastewater by use of zeolite. Waste Manag 21, 671-6.

13. Dhande VV, Badwaik VB, Aswar AS (2007) Hydrazone as complexing agent: Synthesis, structural characterization and biological studies of some complexes. Russ J Inorg Chem 52, 1206-10.

14. Kachru DN, Khandelwal S, Tandon SK (1989) Influence of methionine supplementation in chelation of lead in rats. Biomed Environ Sci 2, 265-70.

15. Meydani M, Hathcock JN (1984) Effect of dietary methionine on methylmercury and atrazine toxicity. Drug Nutr Interact 2, 217-33.

16. Azizi SN, Ehsani-Tilami S (2009) Recrystallization of zeolite $\mathrm{Y}$ to analcime and zeolite $\mathrm{P}$ with D-methionine as structure-directing agent (SDA). Z Anorg Allg Chem 635, 2660-4.

17. Sprynsky M, Buszewski B, Terzyk AP, Namiesnik J (2006) Study of the selection mechanism of heavy metal $\left(\mathrm{Pb}^{2+}, \mathrm{Cu}^{2+}, \mathrm{Ni}_{2}^{+}\right.$, and $\left.\mathrm{Cd}^{2+}\right)$ adsorption on clinoptilolite. $J$ Colloid Interface Sci 304, 21-8.

18. Mintova S, Valtchev V, Kanev I (1995) Structurecontrolled effect of organic templates on zeolite crystallization. Mol Eng 4, 369-73.

19. Seco A, Gabald C, Marzal P, Aucejo A (1999) Effect of $\mathrm{pH}$, cation concentration and sorbent concentration on cadmium and copper removal by a granular activated carbon. $J$ Chem Tech Biotechnol 74, 911-8.

20. Ferris NS, Woodruff WH, Rorabacher DB, Jones TE, Ochrymowycz LA (1978) Resonance Raman spectra of copper-sulfur complexes and the blue copper protein question. $J$ Am Chem Soc 100, 5939-42.

21. Hannan JP, Davy S, Moore GR, Eady RR, Andrew CR (1998) Effect of nickel(II) substitution on the resonance Raman and NMR spectra of Alcaligenes xylosoxidans azurin II: implications for axial-ligand bonding interactions in cupredoxin active sites. $J$ Biol Inorg Chem 3, 282-91. 